\title{
Group II Metabotropic Glutamate Receptor Modulation of DOl-induced c-fos mRNA and Excitatory Responses in the Cerebral Cortex
}

\author{
Yan Zhai', Carolyn A George', Jin Zhai', Eric S Nisenbaum', Michael P Johnson' and Laura K Nisenbaum*,' \\ 'Lilly Research Laboratories, Neuroscience Research Division, Eli Lilly and Company, Lilly Corporate Center, Indianapolis, IN, USA
}

\begin{abstract}
Recent studies have demonstrated that the hallucinogen I-(2,5-dimethoxy-4-iodophenyl)-2-aminopropane (DOI) enhances glutamatergic transmission in the prefrontal cortex. This increase can be suppressed by metabotropic glutamate2/3 (mGlu2/3) receptor activation. In addition to enhancing glutamatergic transmission, DOI increases cortical c-fos expression. We tested if a reduction in glutamate release produced by $\mathrm{mGlu2/3}$ receptor activation attenuates DOI-induced c-fos expression in the cortex. Similar to previous studies, DOI produced a robust increase in c-fos mRNA throughout the cortex, including the prefrontal, frontoparietal, and somatosensory regions. Pretreatment with the mGlu2/3 agonist LY379268 attenuated the DOl-induced increase in the prefrontal cortex. This suppression was blocked by the mGlu2/3 antagonist LY34I495. In contrast, the DOl-induced increase in c-fos mRNA in the frontoparietal and somatosensory cortex was unaffected by the mGlu2/3 agents. These findings suggest that Group II metabotropic glutamate receptor agonists are capable of modulating postsynaptic function preferentially in the limbic cortex under conditions of enhanced glutamate release.

Neuropsychopharmacology (2003) 28, 45-52. doi: I0.1038/sj.npp. I3000 I 3
\end{abstract}

Keywords: mGlu2/3 receptors; prefrontal cortex; immediate early gene; 5-HT2A/2C receptors; LY379268

\section{INTRODUCTION}

Metabotropic glutamate (mGlu) receptors are a family of type III G-protein-coupled receptors that are activated by the excitatory amino acid neurotransmitter glutamate. The mGlu receptors can be subdivided into three groups (Group I: mGlu1,5; Group II: mGlu2,3; Group III: mGlu4,6,7,8) based on sequence homology, signal transduction pathways and pharmacology (Conn and Pin, 1997; Schoepp et al, 1999). Of these subclasses, Group II receptors are often localized presynaptically on axon terminals, acting as autoor heteroreceptors to limit the release of glutamate or other neurotransmitters (Cartmell and Schoepp, 2000). Immunocytochemical studies have demonstrated that mGlu2 receptors are preferentially located adjacent to, rather than in, the synaptic cleft (Shigemoto et al, 1997). This restricted distribution pattern of mGlu2 receptors has led to the hypothesis that these autoreceptors are activated primarily when the concentration of glutamate is increased and is able to diffuse away from the synapse (Kilbride et al, 1998). Consistent with this hypothesis, recent electrophysiological

\footnotetext{
*Correspondence: Dr LK Nisenbaum, Eli Lilly and Company, Neuroscience Research Division, Lilly Research Laboratories, Lilly Corporate Center, Indianapolis, IN 46285, USA, Tel: + I 317433285 I, Fax: + 317276 5546, E-mail: I.nisenbaum@lilly.com Received 6 February 2002; revised 19 June 2002; accepted 20 June 2002
}

data have shown that suppression of excitatory responses of hippocampal $\mathrm{CA}_{3}$ neurons by Group II mGlu receptors (presumably mGlu2) is only apparent during conditions of elevated glutamate release such as following high-frequency stimulation of mossy fibers or blockade of glutamate reuptake (Scanziani et al, 1997).

Excessive release of glutamate has been suggested to contribute to the symptoms of several disorders, including schizophrenia (Aghajanian and Marek, 1999; Krystal et al, 1999). Consistent with this hypothesis, in vitro electrophysiological studies have demonstrated that hallucinogenic drugs such as the serotonin $(5-\mathrm{HT})_{2 \mathrm{~A} / 2 \mathrm{C}}$ receptor agonist 1-(2,5-dimenthoxy-4-iodophenyl)-2-aminopropane (DOI) enhance glutamatergic synaptic transmission in the prefrontal cortex of rats (Marek et al, 2000). One postsynaptic consequence that has been associated with glutamate receptor activation is an upregulation of the immediate early gene, c-fos (Hughes and Dragunow, 1995; Platenik et al, 2000). As such, administration of DOI results in an increase in the expression of c-fos in several regions of the cortex, including prefrontal, frontoparietal, and somatosensory cortices (Leslie et al, 1993; Abi-Saab et al, 1999; Scruggs et al, 2000). In other experiments, DOI has been shown to produce behavioral deficits in animals analogous to those seen in schizophrenics, including stereotypical behaviors and disruption of prepulse inhibition (Varty and Higgins, 1995; Gewirtz and Marek, 2000). These behavioral 
deficits can be attenuated by a functional reduction in glutamate release (Gewirtz and Marek, 2000). Similarly, the enhancement of c-fos expression by DOI can be reversed following blockade of postsynaptic glutamate AMPA receptors, indicating the dependence of these changes on glutamate release (Scruggs et al, 2000). An implication of these data is that suppressing enhanced glutamate release also should have similar effects on DOI-induced c-fos expression.

One approach to reducing glutamate release may be through activation of presynaptic Group II mGlu receptors. Indeed, the potent and selective mGlu2/3 receptor agonist LY354740 ((+)-2-aminobicyclo[3.1.0] hexane-2,6-dicarboxylate) has been shown to suppress both phencyclidine (PCP)induced glutamate release and DOI-enhanced excitatory synaptic transmission in the prefrontal cortex (Moghaddam and Adams, 1998; Marek et al, 2000). In addition, LY354740 reverses the behavioral deficits produced by these compounds (Moghaddam and Adams, 1998; Gewirtz and Marek, 2000). In light of these findings, the present experiments have tested the hypothesis that a reduction of glutamate release produced by activation of Group II mGlu receptors with LY379268 (a structural analog of LY354740) will lead to an attenuation of the increase in c-fos expression in the prefrontal cortex induced by DOI administration.

\section{MATERIALS AND METHODS}

\section{Compounds}

1-(2,5-Dimethoxy-4-iodophenyl)-2-aminopropane $\mathrm{HCl}$ (DOI) was purchased from RBI (Natick, MA). LY379268 and LY341495 were synthesized at Lilly Research Laboratories (Indianapolis, Indiana, USA) as previously described (Ornstein et al, 1998a,b; Monn et al, 1999).

\section{Electrophysiology}

All experiments were performed in accordance with the Guide for the Care and Use of Laboratory Animals as adopted and promulgated by the National Institutes of Health. Coronal prefrontal cortical slices were prepared from young (14-22 days old) male Sprague-Dawley rats as previously described (Baumbarger et al, 2001). Rats were deeply anesthetized with methoxyflurane and decapitated. Their brains were removed rapidly from the skull and immersed in a cold $\left(\sim 2^{\circ} \mathrm{C}\right) \mathrm{NaHCO}_{3}$-buffered saline solution (concentrations in $\mathrm{mM}$ ): $\mathrm{NaCl} 125.0, \mathrm{KCl} 3.0$, $\mathrm{CaCl}_{2}$ 2.4, $\mathrm{MgCl}_{2}$ 1.3, $\mathrm{NaHCO}_{3}$ 26.0, glucose 10.0; $\mathrm{pH}=7.4$, osmolarity $=300 \pm 5 \mathrm{mOsm}$. The brains were blocked and $300 \mu \mathrm{m}$ thick coronal sections were cut through the rostrocaudal extent of the prefrontal cortex. After at least $1 \mathrm{~h}$ of incubation, individual slices were transferred to a recording chamber mounted on an upright microscope and continuously superfused $(2-3 \mathrm{ml} / \mathrm{min})$ with the oxygenated saline solution maintained at $30 \pm 0.2^{\circ} \mathrm{C}$. Differential interference videomicroscopy (Dodt and Zieglgansberger, 1990) was used to visualize pyramidal neurons in the prefrontal cortex. Whole-cell current-clamp recordings were conducted using patch pipettes fabricated from thinwalled borosilicate glass having resistances of 1-4 M 2 . The pipette solution contained (in $\mathrm{mM}$ ) $\mathrm{K}^{+}$-gluconate $130.0, \mathrm{KCl}$
10.0, $\mathrm{MgCl}_{2}$ 2.0, EGTA 1.0, HEPES 10.0, $\mathrm{Na}_{2} \mathrm{ATP} 2.0, \mathrm{Na}_{2} \mathrm{GTP}$ $0.3 ; \quad \mathrm{pH}=7.3$, osmolarity $=300 \pm 5 \mathrm{~m}$ Osm. For some experiments, voltage-dependent $\mathrm{Na}^{+}$currents were blocked by inclusion of QX314 (1 mM) in the pipette solution. The extracellular solution was identical to the $\mathrm{NaHCO}_{3}$-buffered saline solution described above. For some experiments, $\gamma$-aminobutyric $\operatorname{acid}_{\mathrm{A}}$ and $\mathrm{B}$ receptors were blocked with bicuculline methiodide $(1-2 \mu \mathrm{M})$ and SCH59011 $(2 \mu \mathrm{M})$, respectively. Voltage signals were amplified by an Axoclamp 200B amplifier (Axon Instruments, Foster City, CA), lowpass filtered at $5 \mathrm{kHz}$, and stored on the computer hard disk for off-line analysis (Clampfit 8.0, Axon Instruments). Postsynaptic potentials were evoked by constant current single-stimulation pulses $(100 \mu \mathrm{s}, 50-500 \mu \mathrm{A})$ delivered with a $20 \mathrm{~s}$ interstimulus interval using bipolar stimulating electrodes positioned in the cell body layer.

\section{In Situ Hybridization}

Male, Sprague-Dawley rats (Harlan Laboratories, Indianapolis, IN) weighing approximately $200 \mathrm{~g}$ at the time of study were used. Animals were housed five per cage in a temperature-controlled room on a 12:12 h light/dark cycle. Food and water were available ad libitum.

Five groups of rats ( $n=6$ per group) received a series of three injections spaced $20 \mathrm{~min}$ apart. Injection 1, vehicle (sterile water) or LY341495 (3 mg/kg, s.c.), occurred at $t=0 \mathrm{~min}$; injection 2, vehicle (sterile water) or LY379268 ( $15 \mathrm{mg} / \mathrm{kg}$, i.p.), occurred at $t=20 \mathrm{~min}$; injection 3, vehicle (sterile water) or DOI $(12 \mathrm{mg} / \mathrm{kg}$, i.p.), occurred at $t=40 \mathrm{~min}$. This dose of DOI was chosen to ensure a supramaximal effect. Animals were killed $2 \mathrm{~h}$ after the last injection. Brains were removed, rapidly frozen in isopentane cooled on dry ice, and stored at $-70^{\circ} \mathrm{C}$. Coronal sections $(12 \mu \mathrm{m})$ were cut on a cryostat and assayed for c-fos mRNA levels by in situ hybridization histochemistry. LY379268 is a highly selective mGlu2/3 agonist with $>100$-fold selectivity over mGlu1, 5, 4, 7, and 8 (Monn et al, 1999; Schoepp et al, 1999). Similarily, LY341495 is a nanomolar potent competitive antagonist for mGlu2/3 receptors with some selectivity against mGlu8 (10-fold) but much greater selectivity against the other mGlu receptors (Kingston et al, 1998; Schoepp et al, 1999). Thus, the maximally effective dose of LY379268 utilized here would, most likely, selectively activate the mGlu2 and 3 receptors and pretreatment with the antagonist LY341495 would be expected to partially prevent this mGlu2/3mediated activity.

DNA templates for synthesizing RNA probes were constructed using PCR. Rat genomic DNA (Clontech) was used as template. The primers contained gene-specific sequences in addition to either T7 or T3 promoter sequences. The c-fos probe was $270 \mathrm{bp}$ corresponding to nucleotides $1414-1684$ of the rat c-fos sequence (GenBank No. X06769). Standard PCR amplification was performed for 30 cycles with an annealing temperature of $46^{\circ} \mathrm{C}$. Onetenth of the reaction was used as a template for a second PCR reaction using the same conditions. The PCR product was gel purified and sequenced to verify its identity. Radiolabeled RNA probes were synthesized using Maxiscript in vitro transcription kit (Ambion) with $20 \mathrm{ng}$ of PCR generated templates and $5 \mu \mathrm{l}$ of ${ }^{35}$ S-UTP. 
Prior to hybridization, sections were postfixed in $4 \%$ paraformaldehyde, acetylated with $0.25 \%$ acetic anhydride in $0.1 \mathrm{M}$ triethanolamine, dehydrated in a graded alcohol series, delipidated in chloroform, and then rehydrated and air dried. Sections were hybridized with $\left[{ }^{35} \mathrm{~S}\right]$-labeled c-fos $\left(1 \times 10^{6} \mathrm{cpm} /\right.$ slide $)$ for $18 \mathrm{~h}$ at $55^{\circ} \mathrm{C}$ in buffer containing $50 \%$ formamide, $50 \mathrm{mM}$ Tris, $2.5 \mathrm{mM}$ EDTA, $0.2 \mathrm{M} \mathrm{NaCl}$, $10 \%$ dextran, $1 \times$ Denhardt's, $50 \mathrm{mM}$ DTT, and $250 \mathrm{mg} / \mathrm{ml}$ tRNA. After hybridization, the sections were washed at room temperature (RT) with $4 \times \mathrm{SSC} / 2 \mathrm{mM}$ DTT for $5 \mathrm{~min}$ three times, dehydrated in graded ethanol solutions, washed in formamide buffer $(0.3 \mathrm{M} \mathrm{NaCl}, 50 \%$ formamide, $20 \mathrm{mM}$ Tris $\mathrm{pH} 7.5,1 \mathrm{mM}$ EDTA, $10 \mathrm{mM}$ DTT) for $10 \mathrm{~min}$ at $60^{\circ} \mathrm{C}$, and allowed to cool in $2 \times \mathrm{SSC} / 2 \mathrm{mM}$ DTT. The sections were then treated with RNase A $(20 \mu \mathrm{g} / \mathrm{ml})$ for $30 \mathrm{~min}$ in buffer $(0.5 \mathrm{M} \mathrm{NaCl}, 10 \mathrm{mM}$ Tris $\mathrm{pH} 8,1 \mathrm{mM}$ EDTA, $10 \mathrm{mM}$ DTT) preheated to $37^{\circ} \mathrm{C}$. Sections were subsequently washed in $2 \times \mathrm{SSC} / 2 \mathrm{mM}$ DTT, $1 \times \mathrm{SSC} / 2 \mathrm{mM} \mathrm{DTT}$, $0.5 \times \mathrm{SSC} / 2 \mathrm{mM} \mathrm{DTT}$ for $5 \mathrm{~min}$ each and then $0.1 \times \mathrm{SSC} /$ $10 \mathrm{mM} \mathrm{DTT}$ at $50^{\circ} \mathrm{C}$ for $15 \mathrm{~min}$. Slides were cooled in $0.1 \times \mathrm{SSC} / 2 \mathrm{mM}$ DTT at RT before being dehydrated in graded ethanol solutions. The sections were dried and exposed to Biomax MR-1 film (Kodak) for 6 days. The specificity of the hybridization was confirmed by demonstrating that the $\left[{ }^{35} \mathrm{~S}\right]$-labeled sense riboprobe did not yield any significant hybridization.

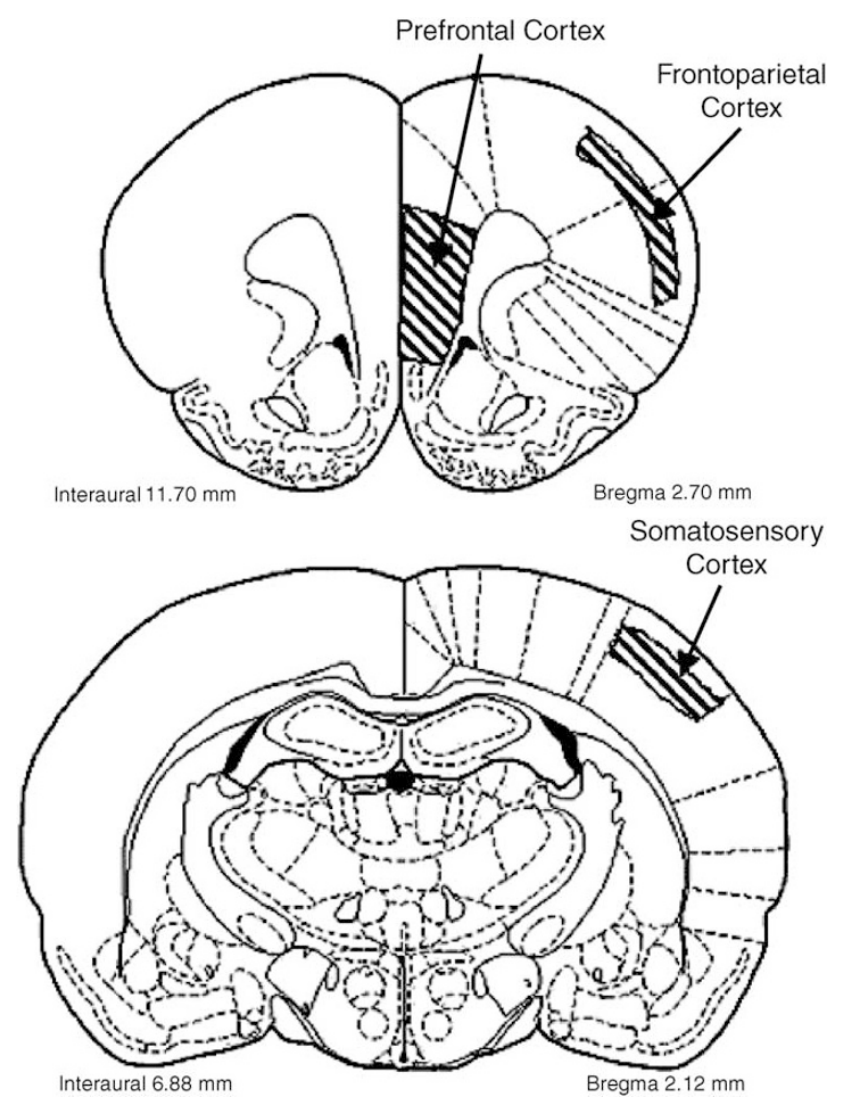

Figure I Schematic illustration of the sites for c-fos analysis. The sections were taken at the indicated anterior-posterior coordinates based on the atlas of Paxinos and Watson (1998). The hatched regions illustrate the areas in which c-fos mRNA were measured.
Digitized image analysis of the autoradiograms was achieved by illuminating the X-ray films with a Northern Light lightbox (Imaging Research Inc., St Catherines, ON). The images were captured with a Sony XC-77 CCD video camera coupled to a Dell Dimension XPS R400 computer. The data were quantified using the MCID M5 image analysis system (Imaging Research Inc., St Catherines, ON). The optical density values were measured in the prefrontal cortex (PrL and IL), frontoparietal cortex (M1 and S1J), and somatosensory cortex (S1BF) for each animal (Figure 1) (Paxinos and Watson, 1998). The mean density values were measured separately in both hemispheres for each area of cortex and the corpus callosum. To correct for background variation, the mean density value of the corpus callosum was subtracted from each cortical section for the corresponding hemisphere. The subtracted mean density values for both hemispheres were then averaged. The average value for each animal was then used to determine the group mean, which was expressed as a percent of control (mean \pm SEM). Statistical analyses were carried out using the GraphPad Prism program. Statistical significance was determined using a one-way ANOVA. Post hoc comparisons were conducted using the Neuman-Keuls test for multiple comparisons. The level of significance was set at $p<0.05$ for all comparisons.

\section{RESULTS}

In initial studies the modulatory effects of the mGlu2/3 receptor agonist LY379268 on excitatory glutamatergic synaptic inputs to prefrontal cortical layer V-VI pyramidal neurons were evaluated in the presence of antagonists of $\mathrm{GABA}_{\mathrm{A}}$ and $в$ receptors. Because of the dense recurrent excitatory collateral network among prefrontal cortical pyramidal neurons, the synaptic response evoked by local stimulation is comprised of both mono- and polysynaptic components, yielding a complex excitatory postsynaptic potential (EPSP) (Figure 2a). Application of LY379268 $(0.01-1.0 \mu \mathrm{M})$ suppressed the EPSP in a concentrationdependent manner (Figure 2a and $b$ ). This suppression was produced in the absence of any change in resting membrane potential or input resistance, suggesting that LY379268 acted at presynaptic mGlu2/3 receptors to inhibit glutamate release.

The actions of the $5-\mathrm{HT}_{2 \mathrm{~A} / 2 \mathrm{C}}$ agonist DOI on the complex EPSPs evoked in prefrontal cortical pyramidal neurons were next explored. Previous studies have demonstrated that DOI enhances excitatory responses in prefrontal cortical pyramidal neurons, presumably by acting on presynaptic receptors to facilitate glutamate release (Marek et al, $2000)$. Consistent with these findings, DOI $(3 \mu \mathrm{M})$ enhanced the amplitude of the complex EPSP evoked in pyramidal neurons by approximately $30 \%$ (Figure $2 \mathrm{c}$ and $\mathrm{d}$ ). This enhanced response was suppressed by subsequent application of LY379268 $(0.01-1.0 \mu \mathrm{M})$. Interestingly, the lowest concentration $(0.01 \mu \mathrm{M})$ of LY379268 was effective in the presence, but not in the absence, of DOI (Figure $2 \mathrm{~b}$ and $\mathrm{d}$ ). The reduced response produced by LY379268 was blocked by the mGlu2/3 receptor antagonist LY341495 $(1.0 \mu \mathrm{M})$ (Figure $2 \mathrm{e}$ and $\mathrm{f}$ ). Collectively, these results demonstrate that excitatory glutamatergic responses of prefrontal 


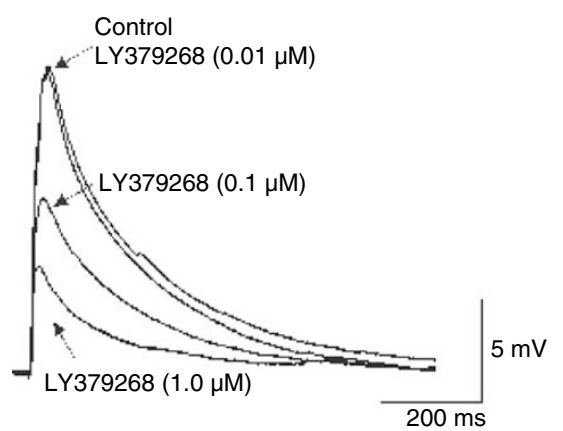

C
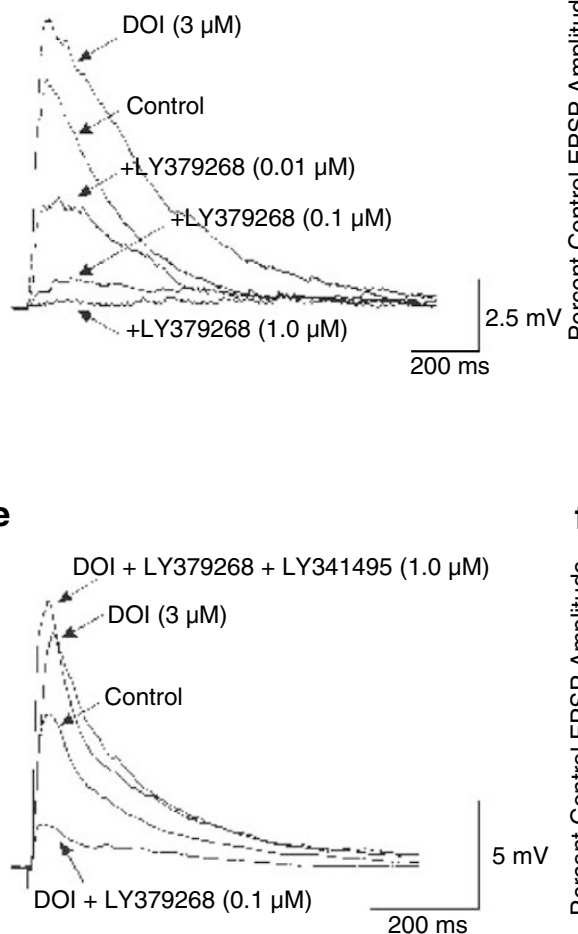

b

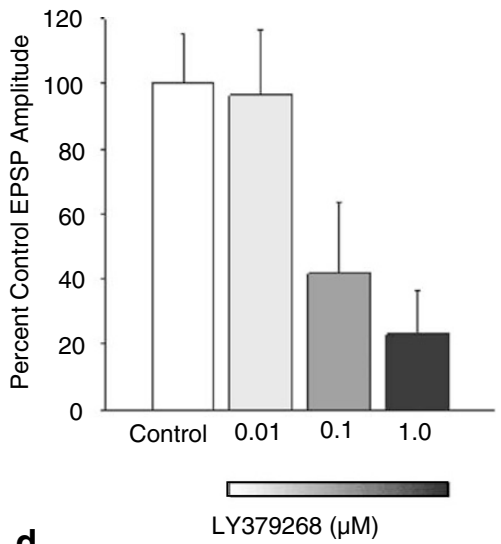

d
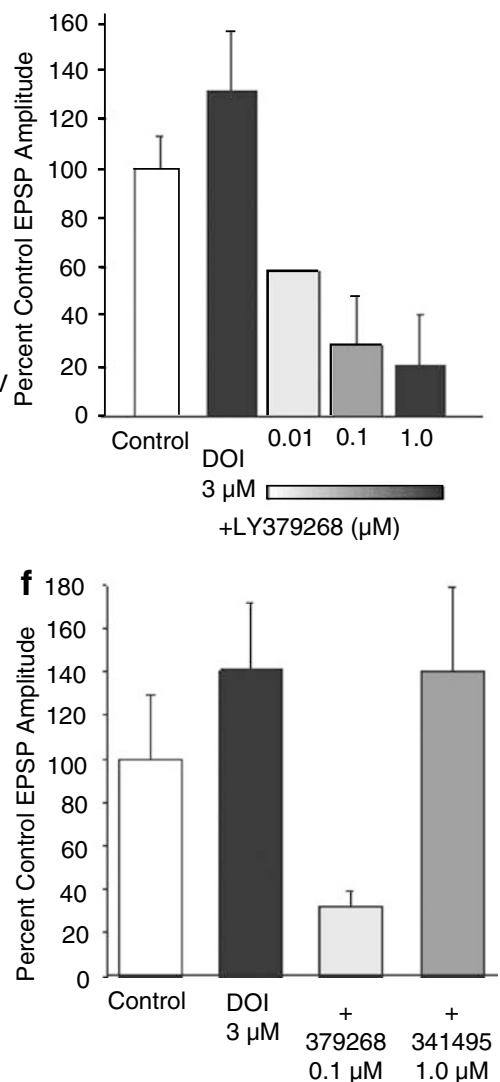

Figure 2 Activation of $\mathrm{mGlu2/3}$ receptors suppresses the DOl-induced enhancement of EPSPs in vitro. (a) Single stimulation of glutamatergic afferents to prefrontal cortical pyramidal neurons evokes a complex EPSP composed of both mono- and polysynaptic components. Application of LY379268 (0.0 I$1.0 \mu \mathrm{M}$ ) reduces the EPSP in a concentration-dependent manner. (b) Histogram of the effect of LY379268 on EPSP amplitude as a percent of the control response amplitude. (c) DOI $(3 \mu \mathrm{M})$ enhances the evoked response in prefrontal neurons, an effect that is suppressed by subsequent application of LY379268 (0.0 I-I.0 $\mu \mathrm{M})$. (d) Histogram of the effect of DOI alone and in combination with LY379268 on EPSP amplitude. (e) The suppression of the DOIenhanced response can be reversed by LY34I 495 (I.0 $\mu$ M). (f) Histogram of the effects of DOI alone and in conjunction with LY379268 and LY34I 495 on EPSP amplitude.

cortical pyramidal neurons can be positively and negatively modulated by $5-\mathrm{HT}_{2 \mathrm{~A} / 2 \mathrm{C}}$ and $\mathrm{mGlu} 2 / 3$ receptors, respectively.

To examine the functional consequences of mGlu2/3 receptor activation in the prefrontal cortex, we measured the expression of c-fos mRNA using in situ hybridization histochemistry. Previous studies have shown that DOI produces an increase in Fos protein in the prefrontal cortex (Abi-Saab et al, 1999). Consistent with these findings, systemic administration of DOI $(12 \mathrm{mg} / \mathrm{kg}$, i.p.) increased c-fos mRNA in the prefrontal cortex (Figures 3 and $4 \mathrm{a}$ ). The overall ANOVA revealed a significant effect of treatment on c-fos expression $(\mathrm{F}(4,26)=14.71, P<0.0001)$. The post hoc Newman-Keuls test revealed that DOI significantly increased c-fos relative to vehicle $(P<0.001)$, and prior administration of the mGlu2/3 agonist LY379268 (15 mg/ $\mathrm{kg}$, i.p.) significantly reduced the effect of DOI on c-fos mRNA levels $(P<0.05)$. The reduced $c$-fos response 


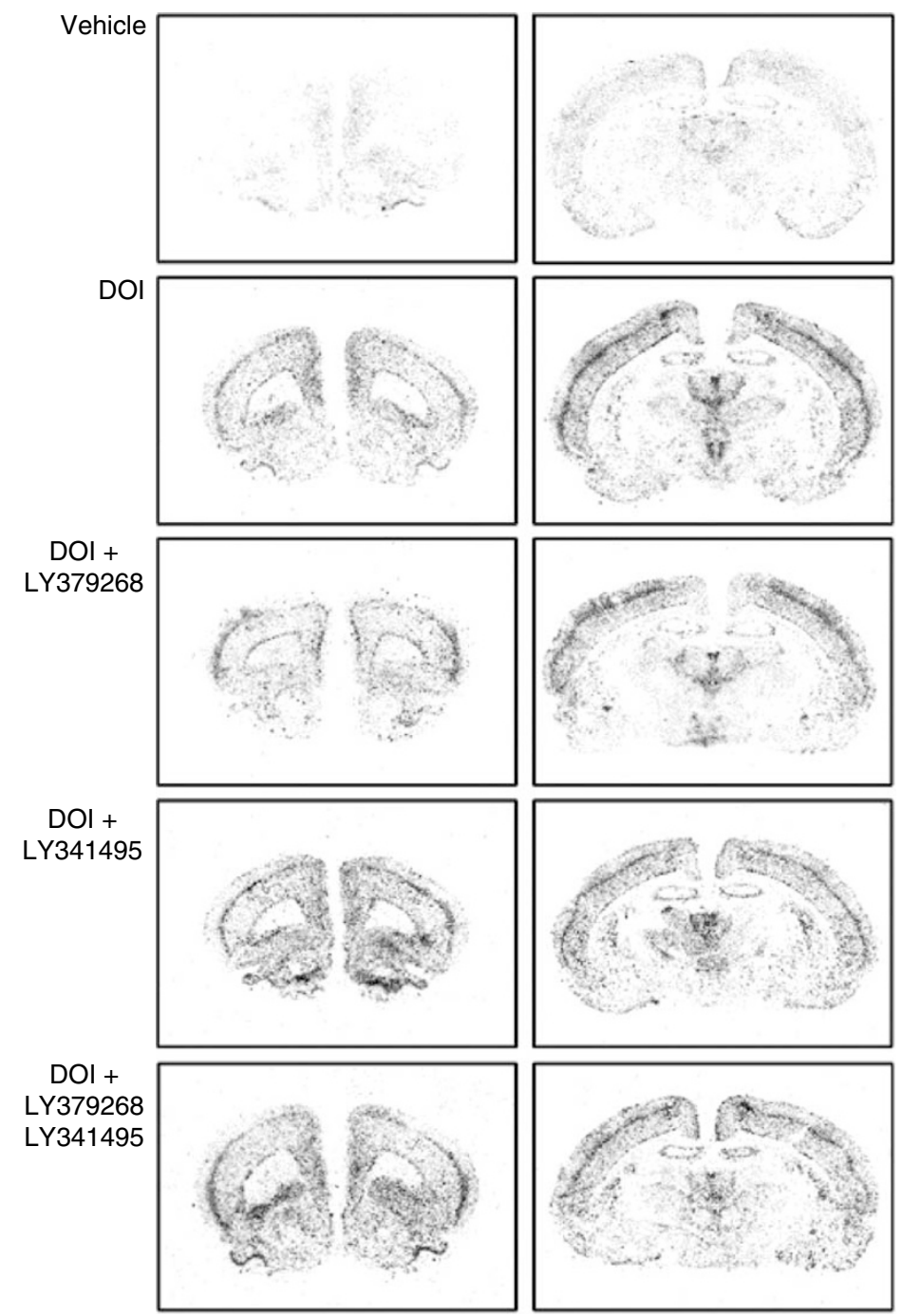

Figure 3 In situ hybridization histochemical localization of c-fos mRNA. Digitized photomicrographs show an increase in c-fos expression in response to $\mathrm{DOI}(12 \mathrm{mg} / \mathrm{kg}$, i.p.) in various regions throughout the forebrain, including the prefrontal cortex, frontoparietal cortex, and somatosensory cortex. The mGlu2/3 agonist LY379268 (I5 mg/kg, i.p.) attenuates the DOI-induced increase in c-fos in the prefrontal cortex, but not in the frontoparietal and somatosensory cortex. Pretreatment with the mGlu2/3 antagonist LY34I495 (3 mg/kg, s.c.) blocks the suppression of the DOI-induced increase by LY379268 in the prefrontal cortex. Administration of LY34I495 alone does not alter the DOl-induced response in the three cortical regions.

produced by LY379268 was blocked by the mGlu2/3 antagonist LY341495, suggesting that the effect of LY379268 is mediated through mGlu2/3 receptor activation. Further analysis of the mGlu2/3 agonist effect indicated that the reduction in DOI-induced c-fos expression occurred to a greater extent in the deeper layers than the superficial layers of the prefrontal cortex. However, this difference did not reach statistical significance.

Previously, the ability of the mGlu2/3 agonist LY354740 to modulate 5-HT-induced EPSCs was shown to be greater in the prefrontal cortex than in the frontoparietal cortex (Marek et al, 2000). Therefore, we examined the effect of mGlu2/3 receptor activation on c-fos expression in other regions of the cortex. Similar to the prefrontal cortex, administration of DOI resulted in a significant increase in c-fos mRNA levels in the frontoparietal (overall ANOVA $(\mathrm{F}(4,29)=9.864, p<0.0001))$ and somatosensory (overall ANOVA $(\mathrm{F}(4,28)=82.91, \quad p<0.0001)) \quad$ cortical regions
(Figures 3, 4b and c). However, prior administration of LY379268 or LY341495 did not significantly alter the effect of DOI on c-fos expression.

\section{DISCUSSION}

The present findings provide the first demonstration that mGlu $2 / 3$ receptors are capable of modulating DOI-induced c-fos expression in the prefrontal cortex. Specifically, the potent and selective mGlu2/3 agonist LY379268 attenuated the DOI-induced increase in c-fos mRNA levels observed in the medial prefrontal cortex. This attenuated response was prevented by the mGlu2/3 antagonist LY341495, consistent with an action mediated through mGlu2/3 receptors. These results parallel the observed dose-dependent reduction of DOI-enhanced excitatory responses by LY379268 recorded in prefrontal cortical slices shown here. Together, these 

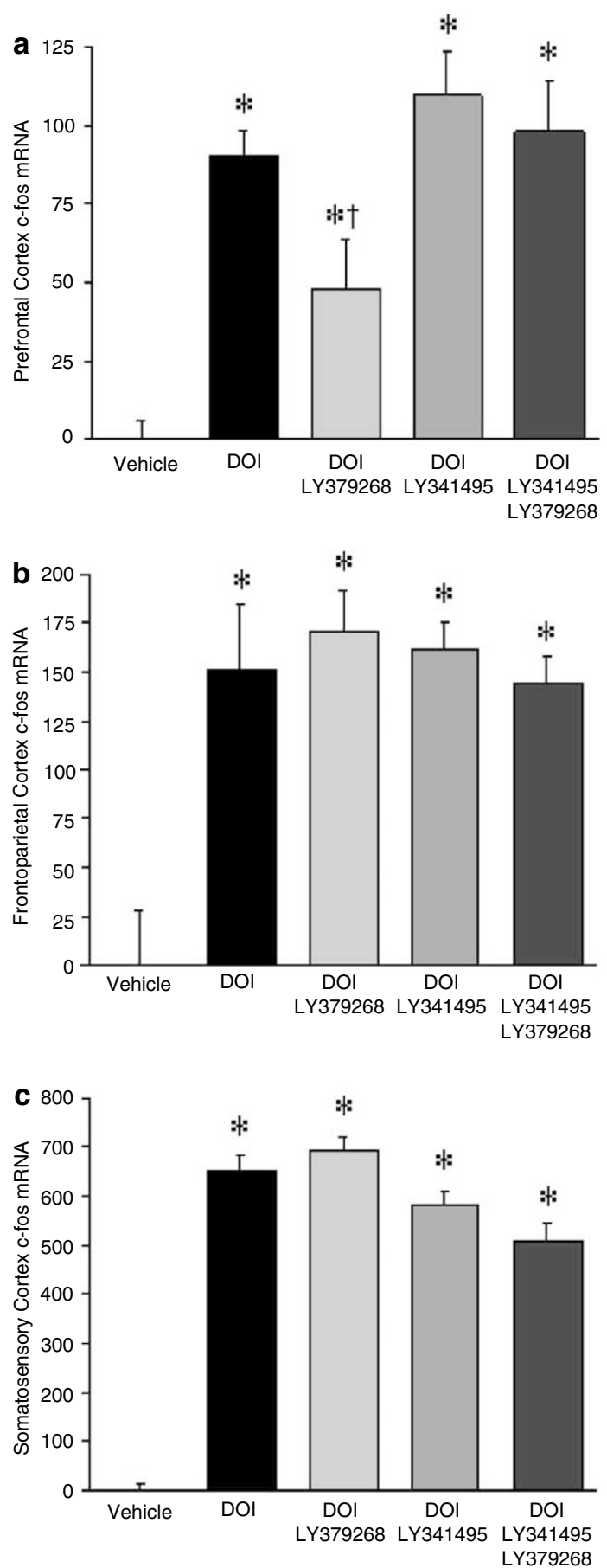

Figure 4 Pretreatment with the $\mathrm{mGlu} 2 / 3$ agonist attenuates the DOIinduced increase in c-fos mRNA in the prefrontal cortex (a) but not in the frontoparietal (b) or somatosensory (c) cortex. $* P \leqslant 0.0$ I relative to vehicle; $* * P \leqslant 0.05$ relative to $\mathrm{DOI}$.

findings demonstrate that mGlu2/3 receptor activation reduces DOI-enhanced glutamate release, resulting in functional alterations in signal transduction within the prefrontal cortex. In contrast to the prefrontal cortex, LY379268 did not alter the DOI-enhanced response in either the frontoparietal or somatosensory cortices. These results indicate that c-fos expression is differentially modulated by mGlu2/3 receptors in limbic $v s$ sensory/motor cortical regions.

In the somatosensory cortex, DOI has previously been shown to increase Fos protein expression within a band of neurons spanning superficial layer $\mathrm{V}$ to deep layer III (Moorman and Leslie, 1996; Mackowiak et al, 1999; Scruggs et al, 2000). This enhancement in Fos expression can be blocked by the selective $5-\mathrm{HT}_{2 \mathrm{~A}}$ antagonist MDL 100907 but not by the $5-\mathrm{HT}_{2 \mathrm{C}}$ antagonist SB 206553, consistent with a 5$\mathrm{HT}_{2 \mathrm{~A}}$-mediated effect of DOI (Scruggs et al, 2000). The vast majority of Fos-positive cells in the somatosensory cortex, however, do not express $5-\mathrm{HT}_{2 \mathrm{~A}}$-like immunoreactivity (Mackowiak et al, 1999; Scruggs et al, 2000), suggesting that the DOI-induced increase in Fos expression is mediated indirectly. Consistent with this possibility, it has been demonstrated that the AMPA/KA antagonist GYKI 52466 is capable of reversing the effect of DOI on Fos expression in the somatosensory cortex (Scruggs et al, 2000). Moreover, lesions of the thalamic afferents to the somatosensory cortex, the ventral posterior medial nucleus of the thalamus, lead to an attenuation of the DOI response (Scruggs et al, 2000). These data suggest that the effect of DOI on Fos is mediated through alterations in glutamate release from thalamocortical afferents. Thus, it has been hypothesized that DOI acts via $5-\mathrm{HT}_{2 \mathrm{~A}}$ receptors located on thalamocortical afferents to increase glutamate release onto nonpyramidal glutamatergic cells, leading to an increase in Fos expression within these neurons (Scruggs et al, 2000). In contrast to the somatosensory cortex, DOI has previously been shown to increase Fos protein expression in both GABAergic interneurons $\left(\mathrm{GAD}_{67}\right.$-positive cells) and in presumed pyramidal neurons $\left(\mathrm{GAD}_{67}\right.$-negative cells) in the prefrontal cortex (Abi-Saab et al, 1999). It is unclear whether this increase in Fos expression is mediated directly through activation of postsynaptic $5-\mathrm{HT}_{2 \mathrm{~A}}$ receptors or indirectly through an increase in glutamate release from thalamocortical afferents (Abi-Saab et al, 1999).

Group II metabotropic receptors have been localized to various regions within the cortex and thalamus (Ohishi et al, 1993a,b; Ohishi et al, 1998; Lourenco Neto et al, 2000). Messenger RNA for both mGlu2 and mGlu3 receptors are found throughout the cortex in both pyramidal and nonpyramidal neurons (Ohishi et al, 1993a,b). Autoradiography using $\left[{ }^{3} \mathrm{H}\right] \mathrm{LY} 354740$ indicates that mGlu2/3 binding is strongest in layers $\mathrm{I}$ and $\mathrm{Va}$ in the medial prefrontal cortex (Marek et al, 2000). These layers also correspond to the area of greatest $5-\mathrm{HT}_{2 \mathrm{~A}}$ receptor density (Marek et al, 2000). Nuclei of the midline and intralaminar thalamus, including the paraventricular, intermediodorsal, and the central medial nuclei, provide dense projections to these same layers (Berendse and Groenewegen, 1991). Moreover, lesions of the medial thalamus result in a significant decrease in mGlu2/3 binding in the medial prefrontal cortex (Marek et al, 2001). Furthermore, a high level of mGlu2, but not mGlu3, mRNA is localized within the midline and intralaminar regions of the thalamus (Ohishi et al, 1993b). Together, these data suggest that both mGlu2 and $5-\mathrm{HT}_{2 \mathrm{~A}}$ receptors may be localized to thalamocortical afferents originating from the midline/intralaminar nuclei of the thalamus. Thus, the attenuation of DOI-induced c-fos expression produced by LY379268 in the prefrontal cortex may be mediated through mGlu2 receptor activation on thalamocortical afferents leading to a reduction in glutamate release onto both pyramidal and interneurons. 
In contrast to the prefrontal cortex, the highest density of mGlu2/3 receptor binding in the frontoparietal cortex is found more superficially in layers II-IV (Marek et al, 2000). The thalamic nuclei that project to the frontoparietal cortex as well as the somatosensory cortex, including the ventrolateral and ventroposterior nuclei, do not express significant levels of mGlu2 mRNA (Ohishi et al, 1993b). Therefore, it is likely that mGlu2 receptors are not found on the thalamocortical afferents within these regions of cortex. This relative scarcity of mGlu2 receptors on thalamocortical afferents may underlie the lack of an effect with LY379268 on DOI-induced c-fos expression in the frontal and parietal cortex as compared to the prefrontal cortex. Consistent with this finding is the previous observation that the mGlu2/3 agonist LY354740 showed a lower potency in suppressing 5HT-induced EPSCs in the frontoparietal cortex compared with the prefrontal cortex (Marek et al, 2000). Together, these data suggest that the differential effect of Group II metabotropic receptor activation on both excitatory responses and immediate early gene expression in prefrontal $v s$ frontoparietal cortex may relate to differential localization of mGlu2/3 receptors within different cortical afferents such as thalamocortical circuits. Alternatively, these effects may result from differential localization of mGlu2 or mGlu3 receptors to intrinsic pyramidal and/or nonpyramidal neurons within the prefrontal and sensory/motor cortical regions. Further studies will be necessary to directly investigate colocalization of $\mathrm{mGlu} 2 / 3$ and $5-\mathrm{HT}_{2 \mathrm{~A}}$ receptors in various cortical regions.

In summary, we have shown that mGlu2/3 receptor activation suppresses both DOI-induced glutamate release, as measured electrophysiologically by EPSPs, and c-fos gene expression in the prefrontal cortex. In contrast, the mGlu2/3 agonist LY379268 is unable to modulate DOI-induced c-fos levels in sensory/motor areas of cortex. Together, these data suggest that Group II metabotropic glutamate receptor agonists are capable of modulating postsynaptic function preferentially in the limbic cortex under conditions of excessive glutamate release. Recent evidence suggests that hyperactivity of glutamatergic systems in the limbic cortex may contribute to the symptoms of schizophrenia (Krystal et al, 1999). The selective modulation of DOI-induced c-fos expression in the prefrontal cortex suggests that mGlu2/3 receptor agonists may provide an effective therapeutic strategy for preferentially targeting areas of glutamatergic dysfunction in schizophrenia.

\section{ACKNOWLEDGEMENTS}

We thank Dr James Monn for the synthesis and supply of LY379268 and LY341495.

\section{REFERENCES}

Abi-Saab WM, Bubser M, Roth RH, Deutch AY (1999). 5-HT2 receptor regulation of extracellular GABA levels in the prefrontal cortex. Neuropsychopharmacology 20: 92-96.

Aghajanian GK, Marek GJ (1999). Serotonin-glutamate interactions: a new target for antipsychotic drugs. Neuropsychopharmacology 21: S122-S123.
Baumbarger PJ, Muhlhauser M, Zhai J, Yang CR, Nisenbaum ES (2001). Positive modulation of alpha-amino-3-hydroxy-5methyl-4-isoxazole propionic acid (AMPA) receptors in prefrontal cortical pyramidal neurons by a novel allosteric potentiator. J Pharmacol Exp Ther 298: 86-102.

Berendse HW, Groenewegen HJ (1991). Restricted cortical termination fields of the midline and intralaminar thalamic nuclei in the rat. Neuroscience 42: 73-102.

Cartmell J, Schoepp DD (2000). Regulation of neurotransmitter release by metabotropic glutamate receptors. J Neurochem 75: 889-907.

Conn PJ, Pin JP (1997). Pharmacology and functions of metabotropic glutamate receptors. Annu Rev Pharmacol Toxicol 37: 205-237.

Dodt HU, Zieglgansberger W (1990). Visualizing unstained neurons in living brain slices by infrared DIC-videomicroscopy. Brain Res 537: 333-336.

Gewirtz JC, Marek GJ (2000). Behavioral evidence for interactions between a hallucinogenic drug and group II metabotropic glutamate receptors. Neuropsychopharmacology 23: 569-576.

Hughes P, Dragunow M (1995). Induction of immediate-early genes and the control of neurotransmitter-regulated gene expression within the nervous system. Pharmacol Rev 47: 133178.

Kilbride J, Huang LQ, Rowan MJ, Anwyl R (1998). Presynaptic inhibitory action of the group II metabotropic glutamate receptor agonists, LY354740 and DCG-IV. Eur J Pharmacol 356: $149-157$.

Kingston AE, Ornstein PL, Wright RA, Johnson BG, Mayne NG, Burnett JP et al (1998). LY341495 is a nanomolar potent and selective antagonist of group II metabotropic glutamate receptors. Neuropharmacology 37: 1-12.

Krystal JH, Belger A, D'Souza DC, Anand A, Charney DS, Aghajanian GK et al (1999). Therapeutic implications of the hyperglutamatergic effects of NMDA antagonists. Neuropsychopharmacology 21: S143-S157.

Leslie RA, Moorman JM, Coulson A, Grahame-Smith DG (1993). Serotonin $2 / 1 \mathrm{C}$ receptor activation causes a localized expression of the immediate-early gene c-fos in rat brain: evidence for involvement of dorsal raphe nucleus projection fibres. $\mathrm{Neu}$ roscience 53: 457-463.

Lourenco Neto F, Schadrack J, Platzer S, Zieglgansberger W, Tolle TR, Castro-Lopes JM (2000). Expression of metabotropic glutamate receptors mRNA in the thalamus and brainstem of monoarthritic rats. Brain Res 854: 93-105.

Mackowiak M, Chocyk A, Fijal K, Czyrak A, Wedzony K (1999). cFos proteins, induced by the serotonin receptor agonist DOI, are not expressed in 5-HT2A positive cortical neurons. Mol Brain Res 71: 358-363.

Marek GJ, Wright RA, Gewirtz JC, Schoepp DD (2001). A major role for thalamocortical afferents in serotonergic hallucinogen receptor function in the rat neocortex. Neuroscience 105: 379392.

Marek GJ, Wright RA, Schoepp DD, Monn JA, Aghajanian GK (2000). Physiological antagonism between 5-hydroxytryptamine(2A) and group II metabotropic glutamate receptors in prefrontal cortex. J Pharmacol Exp Ther 292: 76-87.

Moghaddam B, Adams BW (1998). Reversal of phencyclidine effects by a group II metabotropic glutamate receptor agonist in rats. Science 281: 1349-1352.

Monn JA, Valli MJ, Massey SM, Hansen MM, Kress TJ, Wepsiec JP et al (1999). Synthesis, pharmacological characterization, and molecular modeling of heterobicyclic amino acids related to $(+)$ 2-aminobicyclo[3.1.0] hexane-2,6-dicarboxylic acid (LY354740): identification of two new potent, selective, and systemically active agonists for group II metabotropic glutamate receptors. $J$ Med Chem 42: 1027-1040. 
Moorman JM, Leslie RA (1996). P-chloroamphetamine induces c-fos in rat brain: a study of serotonin $2 \mathrm{~A} / 2 \mathrm{C}$ receptor function. Neuroscience 72: 129-139.

Ohishi H, Neki A, Mizuno N (1998). Distribution of a metabotropic glutamate receptor, mGluR2, in the central nervous system of the rat and mouse: an immunohistochemical study with a monoclonal antibody. Neurosci Res 30: 65-82.

Ohishi H, Shigemoto R, Nakanishi S, Mizuno N (1993a). Distribution of the mRNA for a metabotropic glutamate receptor (mGluR3) in the rat brain: an in situ hybridization study. J Comp Neurol 335: 252-266.

Ohishi H, Shigemoto R, Nakanishi S, Mizuno N (1993b). Distribution of the messenger RNA for a metabotropic glutamate receptor, mGluR2, in the central nervous system of the rat. Neuroscience 53: 1009-1018.

Ornstein PL, Bleisch TJ, Arnold MB, Kennedy JH, Wright RA, Johnson BG et al (1998b). 2-substituted (2SR)-2-amino2-((1SR,2SR)-2-carboxycycloprop-1-yl)glycines as potent and selective antagonists of group II metabotropic glutamate receptors. 2. Effects of aromatic substitution, pharmacological characterization, and bioavailability. J Med Chem 41: 358-378.

Ornstein PL, Bleisch TJ, Arnold MB, Wright RA, Johnson BG, Schoepp DD (1998a). 2-substituted (2SR)-2-amino-2((1SR,2SR)-2-carboxycycloprop-1-yl)glycines as potent and selective antagonists of group II metabotropic glutamate receptors.
1. Effects of alkyl, arylalkyl, and diarylalkyl substitution. J Med Chem 41: 346-357.

Paxinos G, Watson C (1998). The Rat Brain in Stereotaxic Coordinates. 4th edn. Academic Press: San Diego.

Platenik J, Kuramoto N, Yoneda Y (2000). Molecular mechanisms associated with long-term consolidation of the NDMA signals. Life Sci 57: 335-364.

Scanziani M, Salin PA, Vogt KE, Malenka RC, Nicoll RA (1997). Use-dependent increases in glutamate concentration activate presynaptic metabotropic glutamate receptors. Nature 385: 630-634.

Schoepp DD, Jane DE, Monn JA (1999). Pharmacological agents acting at subtypes of metabotropic glutamate receptors. Neuropharmacology 38: 1431-1476.

Scruggs JL, Patel S, Bubser M, Deutch AY (2000). DOI-induced activation of the cortex: dependence on 5-HT2A heteroceptors on thalamocortical glutamatergic neurons. J Neurosci 20: 88468852.

Shigemoto R, Kinoshita A, Wada E, Nomura S, Ohishi H, Takada $M$ et al (1997). Differential presynaptic localization of metabotropic glutamate receptor subtypes in the rat hippocampus. $J$ Neurosci 17: 7503-7522.

Varty GB, Higgins GA (1995). Examination of drug-induced and isolation-induced disruptions of prepulse inhibition as models to screen antipsychotic drugs. Psychopharmacology 122: 15-26. 